\title{
Topical Powder Mix of Chalcanthite, Alum, and Clove as an Effective Feet Odor Treatment
}

\author{
Amera G. Baker \\ Department of Physics, Faculty of Science and Health, Koya University, Danielle Mitterrand Boulevard, Koya KOY45, \\ Kurdistan Region - F.R. Iraq
}

\begin{abstract}
Treating foot odor infected with pathogenic fungus and bacteria has been a major concern for pharmaceutical companies. Finding a right treatment with minimum side effects has been of particular importance. This study configures a homemade topical powder mix in treating foot odor. The homemade topical powder mix is free of any harmful chemical constituents; its main constituents being Chalcanthite, Alum, and Clove. Energy dispersive $\mathrm{X}$-ray fluorescence was used for the determination of the chemical composition component of Chalcanthite, Alum, Clove, and the powder mix of Chalcanthite, Alum, and Clove. X-ray fluoresces techniques was able to measure elements such as oxygen, sulfur, aluminum, potassium, and copper in $\mathrm{k} \alpha$ line. The antimicrobial activity of the powder mix of Chalcanthite, Alum, and Clove was studied against two pathogenic fungi, which are Epidermophyton sp., and Trichophyton sp., and two pathogenic bacteria, which are Brevibacterium sp., and Staphylococcus sp. Screening for antibacterial and antifungal was done using agar disk diffusion. The growth inhibition zone measured ranged from 16 to $28 \mathrm{~mm}$ for all the sensitive fungal, and ranged from 14 to $27 \mathrm{~mm}$ for the sensitive bacteria.
\end{abstract}

Index Terms-Alum, Chalcanthite, Clove, Pathogenic fungus, Topical powder, $\mathrm{X}$-ray fluoresces techniques.

\section{INTRODUCTION}

Foot odor is a type of body odor that affects the feet of humans and is generally considered to be an unpleasant smell. This problem practically is seen among people wearing closed shoes and specifically among sports and army people (Sharquie, et al., 2013). The main cause is foot sweat, sweat itself is odorless, but it creates a beneficial environment for certain bacteria to grow and produce badsmelling substances. These bacteria are naturally present in our skin as part of the human flora (Ara, et al., 2006). The most common type of bacteria is Brevibacterium sp., which is considered a major cause of foot odor because they ingest dead skin on the feet and, in the process, convert amino

ARO-The Scientific Journal of Koya University

Volume VI, No.2 (2018), Article ID: ARO.10299, 6 pages

DOI: $10.14500 /$ aro. 10299

Received 27 August 2017; Accepted 06 July 2018

Regular research paper: Published 13 September 2018

Corresponding author's, e-mail: amera.baker@koyauniversity.org Copyright (C) 2018 Amera G. Baker. This is an open-access article distributed under the Creative Commons Attribution License. acid methionine into methanethiol, which has a sulfuric aroma and cheesy odor (Marshall, et al., 1988). Furthermore, Propionibacteria sp., Staphylococcus sp., and Bacilli sp. that perform fermentation on carbohydrates, proteins, and fatty acids that come from dead skin cells on peoples feet (Kanda, et al., 1990). There are many systemic drugs like topical anti-perspiration agents such as aluminum salts, zinc sulfate solution, and iontophoresis have been used as therapeutic measures (Sharquie, 1996). Furthermore, anticholinergic (glycopyrrolate) and topical antibacterial drugs such as erythromycin, clindamycin, and benzoyl peroxide have been used in the treatment of feet odor (McWilliams, et al., 1987).

Natural products have been used for a long time in treating human disease, and they contain many constituents of therapeutic value, environmentally safer, easily available, and cheap (Oro, et al., 2015).

The present study configures a homemade topical powder mix in treating foot odor. The elements present in the homemade topical powder mix of Chalcanthite, Alum, and Clove can be explored, identified. Concentration calculation of the composites composition has been made using X-ray fluorescence (XRF) techniques. Furthermore, studies were performed on the composites antimicrobial activities against Epidermophyton sp., Trichophyton sp., Brevibacterium sp., and Staphylococcus sp. The homemade topical powder mix of chalcanthite, alum, and clove was practically applied for many people, which has been a successful positive product in the treatment of foot odor. Complete healing was achieved within 3 days of use without the presence of any side effects. The homemade topical powder mix has a nice smell; it is soft on the skin and inexpensive.

\section{Materials AND Methods}

\section{A. Specimens}

Three different materials were purchased from Al Shorja local market, the herbal shop, in Baghdad city, including chalcanthite powder (copper sulfate locally called blue), alum powder (potassium aluminum sulfate), and dried clove (syzygium aromatic). Table I shows the symbols assignments for the used materials.

\section{B. Preparation of powder}

Chalcanthite powder (Z-1), Alum powder (Z-2), and 
TABLE I

Symbols for Materials

\begin{tabular}{ll}
\hline \hline Material & Symbols \\
\hline Chalcanthite & $\mathrm{Z}-1$ \\
Alum & $\mathrm{Z}-2$ \\
Cloves & $\mathrm{Z}-3$ \\
Mix of the three materials & $\mathrm{Z}-123$ \\
\hline \hline
\end{tabular}

dried clove (Z-3) were grinding in a Mini-Mill 2 panalytical milling device to produce a fine powder for each of them. Then, mixing the fine powder of chalcanthite (Z-1), Alum (Z-2), and Clove (Z-3) was carried out to produce a mix of the three materials $(\mathrm{Z}-123)$ at the mixing ratio $(1: 1: 1)$, and was made ready for XRF test. Furthermore, mixing the fine powder of chalcanthite (Z-1), alum (Z-2), and clove (Z-3) was made to produce a mix of the three materials (Z-123) at the mixing ratio $1: 1: 1,1: 0.5: 0.5,0.5: 1: 0.5$ and $0.5: 0.5: 1$, of chalcanthite (Z-1), alum (Z-2), and clove (Z-3), respectively, for antimicrobial activity.

\section{The XRF}

The XRF was performed using Rigaku NEX CG XRF spectrometer. Powder of Z-1, Z-2, and Z-3, was pressed into a pellet of $32 \mathrm{~mm}$ diameter under 10 tons $/ \mathrm{cm}^{2}$ pressures using the hydraulic press. Furthermore, powder of Z-123 was mixed at the ratio (1:1:1), of Z-1, Z-2, and Z-3 and pressed into a pellet of $32 \mathrm{~mm}$ diameter under 10 tons $/ \mathrm{cm}^{2}$ pressures using a hydraulic press. The samples were placed in the chamber and measured by $20 \mathrm{~mm}$ diaphragm in a vacuum. $\mathrm{X}$-ray spectra were obtained using $\mathrm{RX} 9, \mathrm{Cu}, \mathrm{Mo}$, and $\mathrm{Al}$ conditions. In these analyses, the X-ray tube current was set to approximately $1 \mathrm{~mA}$ for RX9 target and into $0.5 \mathrm{~mA}$ for other targets. The X-ray tube voltage has been set to $25 \mathrm{kV}$ for $\mathrm{RX} 9$ and $50 \mathrm{kV}$ for $\mathrm{Cu}, \mathrm{Mo}$, and $\mathrm{Al}$ targets. The X-ray measuring time was 200s for Al target and 100s for other targets.

\section{Microorganisms}

Pure cultures isolated from infected feet are two pathogenic fungi (Epidermophyton sp. and Trichophyton sp.) and two pathogenic bacteria (Brevibacterium sp. and Staphylococcus sp.) were obtained from the Al-Kindi General Hospital in Baghdad city, and diagnosed has been examined in the microbiology laboratory, College of Sciences, University of Baghdad.

The fungi and bacteria isolated cultures were incubated for $24 \mathrm{~h}$ at $37^{\circ} \mathrm{C}$ on potato dextrose agar and nutrient agar medium, respectively, isolated cultures were maintained at $4^{\circ} \mathrm{C}$ (Barbaro and Symonds, 2006; Wayne, 2007). Fungal isolates were grown on potato dextrose agar contained in dilution bottles for approximately 2 weeks. After sufficient incubation, a fungal spore suspension was obtained by aseptically dispensing $10 \mathrm{ml}$ of sterile saline $(0.65 \% \mathrm{NaCl})$ into the bottles and gently removing spores and hyphal fragments from the surface of the plate using a sterile glass rod. Bacterial cultures were grown in $5 \mathrm{ml}$ nutrient broth for 18-24 h. After the 18-24 h incubation period, $100 \mathrm{ml}$ aliquots of culture were aseptically spread over the surface of nutrient agar plates using the spread plate technique.

\section{E. Antimicrobial activity}

The antimicrobial activity susceptibility profiles of two pathogenic fungi and two pathogenic bacteria were investigated by the agar disk diffusion method (Bauer, et al., 1966; CLSI, 2012). The mix of the three materials Z-123 compressed to be suitable for antimicrobial activity test, the pellet is $50 \mathrm{mg}$ with $8 \mathrm{~mm}$ diameter at the mixing ratio $(1: 1: 1,1: 0.5: 0.5,0.5: 1: 0.5$, and $0.5: 0.5: 1)$, of Z-1, Z-2, and $\mathrm{Z}-3$, and screened for their antimicrobial activities against Epidermophyton sp., Trichophyton sp., Brevibacterium sp., and Staphylococcus sp. The zones of growth inhibition around the disks were measured after 3-5 days of an incubation at $28^{\circ} \mathrm{C}$ for fungal, and $18-24 \mathrm{~h}$ of an incubation at $37^{\circ} \mathrm{C}$ for bacteria. The sensitivities of the microorganism species of Z-123 were determined by measuring the sizes of inhibitory zones on the agar surface around the disks.

\section{Results AND Discussions}

\section{A. XRF analysis}

The XRF is working on the principle of absorbing fluorescence by detectors its proportion conductance is a change in the energy of the fluorescence which is processed by the electronics. The signal of fluorescent was measured in kilo-electron volts on the horizontal axis; the vertical axis was an intensity occurrence per second. The energy of the fluorescent determined the elements while the intensity of the fluorescence was identified as the concentration of the elements in a sample, (Peng, et al., 2013; Jang, 2010).

The chemical compositions of components of Z-1, Z-2, Z-3, and Z-123 have detected by the XRF.

Table II, XRF measurements of major, minor and trace elements of Z-1, Z-2, Z-3, and Z-123 (as percentages), the XRF measurements indicated that all the materials are contained oxygen $(\mathrm{O})$, sulfur $(\mathrm{S})$, aluminum ( $\mathrm{Al}$ ), potassium $(\mathrm{K})$, copper $(\mathrm{Cu})$, iron $(\mathrm{Fe})$, zinc $(\mathrm{Zn})$, calcium $(\mathrm{Ca})$, silicon $(\mathrm{Si})$, and chlorite $(\mathrm{Cl})$. However, all the materials were found to have extra elements, copper $(\mathrm{Cu})$ and silicon $(\mathrm{Si})$, which were missing in the case of $\mathrm{Z}-2$ and zinc $(\mathrm{Zn})$ and nickel (Ni) were missing in the case of Z-3. The concentrations of elements are found to be different for all components. Fig. 1, comparison of mass percentage concentrations of selected elements ( $\mathrm{Al}, \mathrm{Cu}, \mathrm{K}, \mathrm{O}$, and $\mathrm{S}$ ) of Z-1, Z-2, Z-3, and Z-123 determined by XRF. It can be observed, in all cases, that oxygen $(\mathrm{O})$ was found to be the highest concentration. Oxygen (O) does not give XRF peaks because fluorescence photons for oxygen are too low in energy to be transmitted through the air and are not efficiently detected using conventional $\mathrm{Si}$ based detectors. Furthermore, the highest concentration of the element is sulfur $(\mathrm{S})$, copper $(\mathrm{Cu})$, aluminum $(\mathrm{Al})$, and potassium (K) which these elements give XRF peaks. When these materials are irradiated with X-rays, the intensity as a function of energy can be calculated over the energy ranges $1-10 \mathrm{keV}$ at the same computing conditions. Fig. 2, intensity versus the energy of $\mathrm{Z}-1$, calculated over the energy range 
TABLE II

X-ray Fluorescence Measurements of Major, Minor, and Trace Elements of Z-1, Z-2, Z-3, and Z-123 (as Percentages)

\begin{tabular}{|c|c|c|c|c|}
\hline Element & Z-1\% & $\mathrm{Z}-2 \%$ & Z-3\% & Z-123\% \\
\hline $\mathrm{O}$ & 72.1 & 71.2 & 93.8 & 71.8 \\
\hline $\mathrm{Cu}$ & 16.8 & - & 0.154 & 8.43 \\
\hline $\mathrm{S}$ & 9.08 & 16.9 & 0.425 & 11.3 \\
\hline $\mathrm{Al}$ & 0.824 & 9.12 & 0.208 & 4.97 \\
\hline $\mathrm{K}$ & 0.0716 & 3.31 & 2.74 & 2.36 \\
\hline $\mathrm{Zn}$ & 0.356 & 0.0012 & - & 0.200 \\
\hline $\mathrm{Ni}$ & 0.0984 & 0.0008 & - & 0.0545 \\
\hline $\mathrm{Si}$ & 0.487 & - & 0.212 & 0.215 \\
\hline $\mathrm{Fe}$ & 0.0571 & 0.0144 & 0.0511 & 0.153 \\
\hline $\mathrm{Ca}$ & 0.0523 & - & 1.20 & 0.305 \\
\hline W & 0.0329 & - & - & 0.0092 \\
\hline $\mathrm{Cr}$ & 0.0120 & 0.0005 & 0.0266 & 0.0032 \\
\hline $\mathrm{Sn}$ & 0.0053 & 0.0044 & - & 0.0064 \\
\hline $\mathrm{Ti}$ & 0.0046 & 0.0021 & - & 0.0038 \\
\hline $\mathrm{Pb}$ & 0.0036 & - & - & 0.0017 \\
\hline $\mathrm{Cl}$ & - & 0.213 & 0.534 & 0.177 \\
\hline $\mathrm{Ta}$ & - & 0.0010 & - & -- \\
\hline $\mathrm{Ga}$ & - & 0.0007 & - & - \\
\hline $\mathrm{V}$ & - & 0.0007 & - & 0.0007 \\
\hline $\mathrm{Rb}$ & - & 0.0006 & - & 0.0023 \\
\hline $\mathrm{Tl}$ & - & - & - & 0.0005 \\
\hline $\mathrm{Sr}$ & - & 0.0004 & - & 0.0017 \\
\hline $\mathrm{Mg}$ & - & - & 0.355 & - \\
\hline $\mathrm{P}$ & - & - & 0.144 & - \\
\hline $\mathrm{Mn}$ & - & - & 0.112 & 0.0150 \\
\hline $\mathrm{Hf}$ & - & - & 0.0387 & - \\
\hline W & - & - & - & 0.0092 \\
\hline $\mathrm{Ag}$ & - & - & - & 0.0003 \\
\hline
\end{tabular}

1-10 keV using XRF with RX9, Mo, $\mathrm{Cu}$, and $\mathrm{Al}$ targets. The peaks are shown in the ranges $1.50,2.31,2.63,6.44,8.058$, and $8.95 \mathrm{keV}$, corresponding to Al-k $\alpha, \mathrm{S}-\mathrm{k} \alpha, \mathrm{Fe}-\mathrm{k} \alpha, \mathrm{Cu}-\mathrm{k} \alpha$, and $\mathrm{Zn}-\mathrm{k} \alpha$ lines. Fig. 3, intensity versus the energy of $\mathrm{Z}-2$, calculated over the energy range $1-10 \mathrm{keV}$ using XRF with $\mathrm{RX} 9, \mathrm{Mo}, \mathrm{Cu}$, and $\mathrm{Al}$ targets. The peaks are shown in the ranges $1.50,2.31,3.35$, and $6.44 \mathrm{keV}$, corresponding to Al$\mathrm{k} \alpha, \mathrm{S}-\mathrm{k} \alpha, \mathrm{K}-\mathrm{k} \alpha$, and Fe-k $\alpha$ lines. Fig. 4, intensity versus the energy of Z-3, calculated over the energy range 1-10 keV using XRF with $\mathrm{RX} 9, \mathrm{Mo}, \mathrm{Cu}$, and $\mathrm{Al}$ targets. The peaks are shown in the ranges $1.76,2.01,2.31,3.35,3.68,5.46,5.91$, $6.44,8.058$, and $8.95 \mathrm{keV}$, corresponding to Si-ka, P-ka, S-k $\alpha, \mathrm{K}-\mathrm{k} \alpha, \mathrm{Ca}-\mathrm{k} \alpha, \mathrm{Cr}-\mathrm{k} \alpha, \mathrm{Mn}-\mathrm{k} \alpha, \mathrm{Fe}-\mathrm{k} \alpha, \mathrm{Cu}-\mathrm{k} \alpha$, and $\mathrm{Zn}-\mathrm{k} \alpha$ lines. Fig. 5, intensity versus the energy of Z-123, calculated over the energy range $1-10 \mathrm{keV}$ using XRF with RX9, Mo, $\mathrm{Cu}$, and $\mathrm{Al}$ targets. The peaks are shown in the ranges 1.50, $2.31,2.63,6.44,8.058$, and $8.95 \mathrm{keV}$, corresponding to Al$\mathrm{k} \alpha$, S-k $\alpha, \mathrm{Fe}-\mathrm{k} \alpha, \mathrm{Cu}-\mathrm{k} \alpha$, and $\mathrm{Zn}-\mathrm{k} \alpha$ lines. The most important elements of $\mathrm{Z}-123$ are sulfur $(\mathrm{S})$, copper $(\mathrm{Cu})$, aluminum $(\mathrm{Al})$, potassium $(\mathrm{K})$, iron $(\mathrm{Fe})$, and zinc $(\mathrm{Zn})$.

\section{B. Antimicrobial activity}

The antimicrobial activity of Z-123 was studied against two pathogenic fungi (Epidermophyton sp., and Trichophyton sp.) and two pathogenic bacteria (Brevibacterium $\mathrm{sp.}$ and Staphylococcus sp.), at the mixing ratio (1:1:1, 1:0.5:0.5, $0.5: 1: 0.5$, and $0.5: 0.5: 1)$, of Z-1, Z-2, and Z-3. The antifungal and

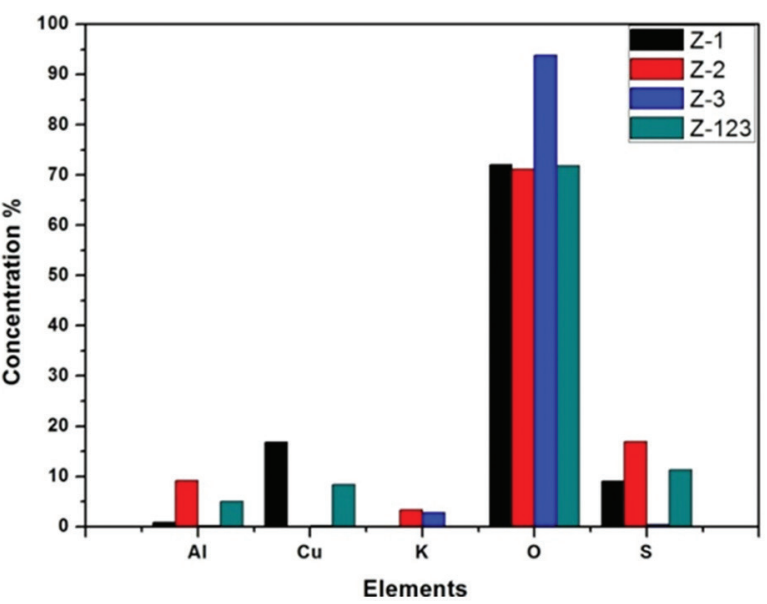

Fig. 1. Comparison of mass percentage concentrations of selected elements ( $\mathrm{Al}, \mathrm{Cu}, \mathrm{K}, \mathrm{O}$, and $\mathrm{S}$ ) of Z-1, Z-2, Z-3, and Z-123, determined by $X$-ray fluorescence.

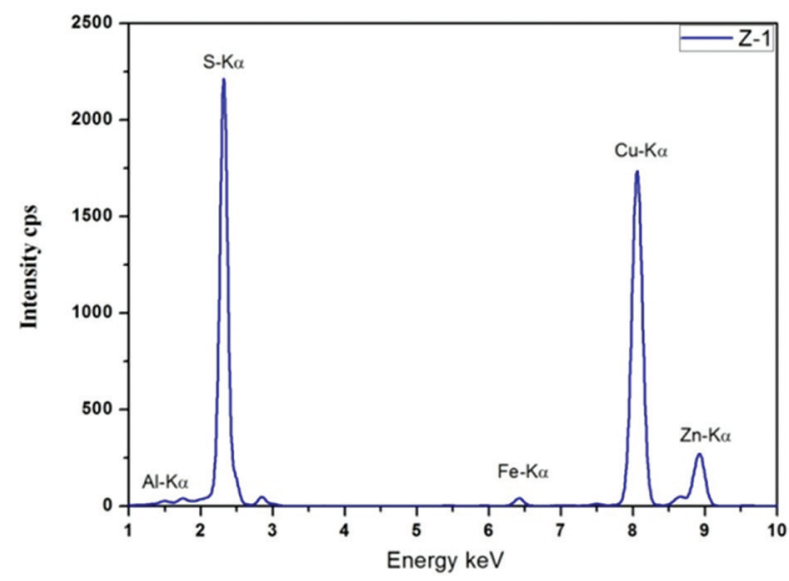

Fig. 2. Intensity versus the energy of Z-1 calculated over the energy range $1-10 \mathrm{keV}$ using $\mathrm{XRF}$ with $\mathrm{RX} 9, \mathrm{Mo}, \mathrm{Cu}$, and $\mathrm{Al}$ targets.

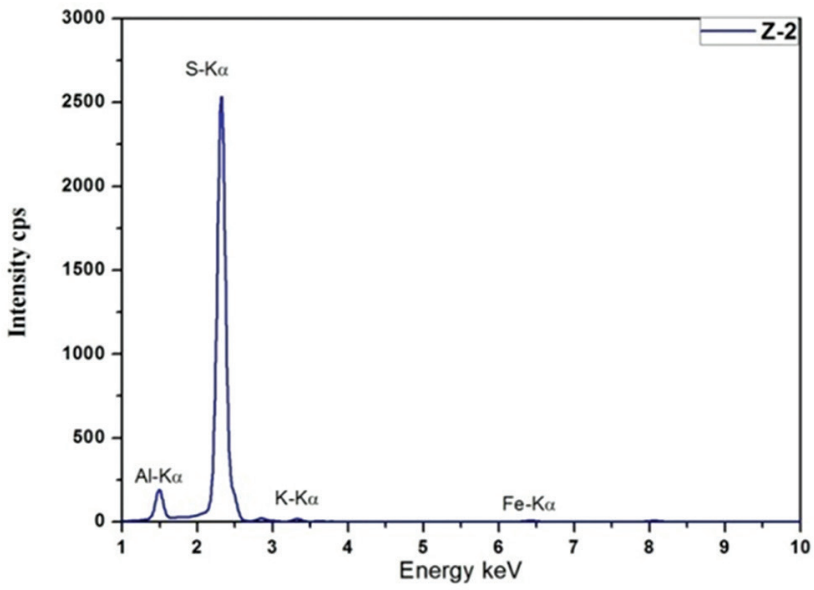

Fig. 3. Intensity versus the energy of Z-2, calculated over the energy range $1-10 \mathrm{keV}$ using $\mathrm{X}$-ray fluorescence with $\mathrm{RX} 9, \mathrm{Mo}, \mathrm{Cu}$, and $\mathrm{Al}$ targets.

antibacterial potential of Z-123 was assessed in terms of zone of inhibition of fungal and bacterial growth. The results are presented 
in Tables III and IV. The growth inhibition zone was found to be high $(28 \mathrm{~mm})$ when mixing Z-1, Z-2, and Z-3 at the same ratio $1: 1: 1$ and the growth inhibition zone was found to be low (14 mm) at the mixing ratio $0.5: 0.5: 1$. The growth inhibition zone measured ranged from 16 to $28 \mathrm{~mm}$ for all the sensitive fungal, and ranged from 14 to $27 \mathrm{~mm}$ for the sensitive bacteria as shown in Fig. 6 .

I have used the topical powder mix of Chalcanthite, Alum, and Clove for many people in Iraq country, in Baghdad, Erbil, and Koya cities. A person who has foot odor was instructed to wash his feet without drying and applies it's between the toes and on the soles of the feet 1 time daily for 3 days only. All the persons who used the topical powder mix assured that complete healing within 3 days only without any side effects recalls after treatment externally on the affected areas. Topical powder mix is an effective therapy for feet infected

TABLE III

Antifungal Activity of Z-123, against Fungal Test Organism

\begin{tabular}{lcc}
\hline \hline Microorganisms & Mixing ratio & Zone of inhibition in $\mathrm{mm}$ \\
\hline Epidermophyton $\mathrm{sp}$. & $1: 1: 1$ & 28 \\
& $1: 0.5: 0.5$ & 20 \\
& $0.5: 1: 0.5$ & 17 \\
Trichophyton $\mathrm{sp}$. & $0.5: 0.5: 1$ & 16 \\
& $1: 1: 1$ & 27 \\
& $1: 0.5: 0.5$ & 21 \\
& $0.5: 1: 0.5$ & 18 \\
\hline \hline
\end{tabular}

TABLE IV

Antibacterial Activity of Z-123, against Bacterial Test Organism

\begin{tabular}{lcc}
\hline \hline Microorganisms & Mixing ratio & Zone of inhibition in $\mathrm{mm}$ \\
\hline Brevibacterium sp. & $1: 1: 1$ & 27 \\
& $1: 0.5: 0.5$ & 23 \\
& $0.5: 1: 0.5$ & 17 \\
Staphylococcus sp. & $0.5: 0.5: 1$ & 15 \\
& $1: 1: 1$ & 26 \\
& $1: 0.5: 0.5$ & 22 \\
& $0.5: 1: 0.5$ & 15 \\
\hline \hline
\end{tabular}

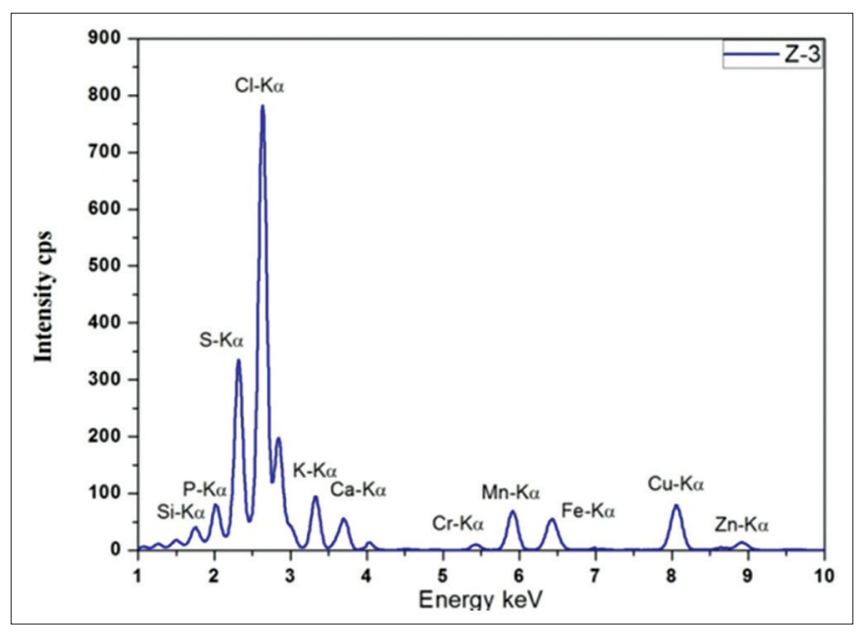

Fig. 4. Intensity versus the energy of Z-3, calculated over the energy range $1-10 \mathrm{KeV}$ using $\mathrm{XRF}$ with $\mathrm{RX} 9, \mathrm{Mo}, \mathrm{Cu}$, and $\mathrm{Al}$ targets.

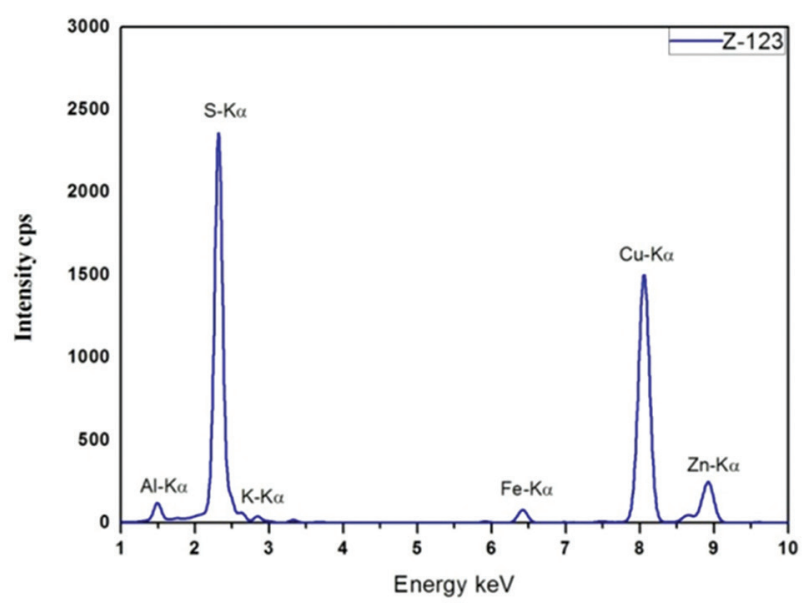

Fig. 5. Intensity versus the energy of Z-123, calculated over the energy range $1-10 \mathrm{KeV}$ using $\mathrm{X}$-ray fluorescencewith $\mathrm{RX} 9, \mathrm{Mo}, \mathrm{Cu}$, and $\mathrm{Al}$ targets.

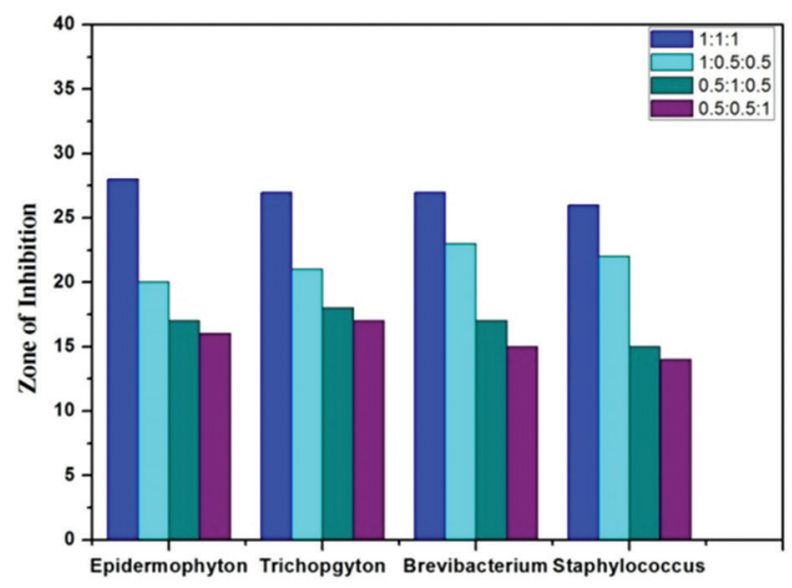

Fig. 6. Zone of inhibition of Z-123 at different mixing ratio versus antifungal and antibacterial activity against Epidermophyton sp.,

Trichophyton sp., Brevibacterium sp., and Staphylococcus.

with pathogenic fungus and bacteria that cause itching, stinging, and burning between the toes and on the soles of the feet, blisters on the feet that itch, cracking and peeling skin on the feet, most commonly between the toes and on the soles, dry skin on the soles or sides of the feet, raw skin on the feet. The topical powder mix has a nice smell, soft on the skin, and inexpensive.

The important elements in the topical powder mix of chalcanthite, alum, and clove are sulfur $(\mathrm{S})$, copper $(\mathrm{Cu})$, aluminum (Al), potassium $(\mathrm{K})$, iron $(\mathrm{Fe})$, and zinc $(\mathrm{Zn})$.

The mechanism of action of the topical powder mix of chalcanthite, alum, and clove related to its multiple effects such as antibacterial, antifungal, and antiperspirant actions. Sulfur is used in pharmaceutical skin preparations for the treatment of acne and other conditions. It acts as a catalytic agent and also kills bacteria, fungi, scabies mites, and other parasites (Kim, et al., 2006; Suleiman, et al., 2015). Many metallic elements have an ability to inhibit the growth of bacteria and to inactivate enzymes. This antimicrobial effect is shown by metals such as mercury, silver, copper, lead, zinc, 
gold, aluminum, and other metals (Peciulyte and DirginciuteVolodkiene, 2102; Percival, et al., 2005). Copper is an essential mineral in the topical powder mix of chalcanthite, alum, and clove that plays a key role in many physiological and metabolic processes, including angiogenesis, skin generation and expression, and stabilization of extracellular skin proteins. Copper has also a potent wide spectrum based properties. The combination of these two distinct properties of copper makes copper a very attractive active material for the improvement of skin well-being (Borkow, 2014). Copper $(\mathrm{Cu})$ and potassium $(\mathrm{K})$ particles were reported to have antimicrobial activity against a wide spectrum of bacteria, including Micrococcus lutes, Klebsiella pneumonia, Escherichia coli, Pseudomonas aeruginosa, Staphylococcus aureus, and Bacillus subtilis (Dawson and Boling, 1987; Yamamoto and Ishihama, 2005). Moreover, $\mathrm{Cu}$ particles have been shown to suppress the vegetative growth of some fungal species such as Aspergillus flavus, Aspergillus niger, Alternaria alternata, Fusarium solani, Penicillium chrysogenum, and Candida albicans (Essa and Khallaf, 2016). The mechanism by which antimicrobial copper kills bacteria is a complex by nature, but the effect is simple. Science suggests that copper surfaces affect bacteria in two sequential steps: The first step is a direct interaction between the surface and the bacterial outer membrane, causing the membrane to rupture. The second is related to the holes in the outer membrane, through which the cell loses vital nutrients and water, causing a general weakening of the cell (Hobman and Crossman, 2014). Every cell's outer membrane, including that of a single cell organism like a bacterium, is characterized by a stable electrical microcurrent. This is often called Trans membrane potential, and is, literally, a voltage difference between the inside and the outside of a cell. It is strongly suspected that when a bacterium comes in contact with a copper surface, a short-circuiting of the current in the cell membrane can occur. This weakens the membrane and creates holes (Smaldone and Helmann, 2007). Another way to make a hole in a membrane is by localized oxidation or rusting. This happens when a single copper molecule, or copper ion, is released from the copper surface and hits a building block of the cell membrane (either a protein or a fatty acid). If the hit occurs in the presence of oxygen, the oxidative damage, or rust will occur. An analogy is rust weakening and making holes in a piece of metal. Now that the cell's main defense (its outer envelope) has been breached, there is an unopposed stream of copper ions entering the cell. This puts several vital processes inside the cell in danger. Copper literally overwhelms the inside of the cell and obstructs cell metabolism. These reactions are accomplished and catalyzed by enzymes. When excess copper binds to these enzymes, their activity grinds to a halt. The bacterium can no longer breathe, eat, digest, or create energy. Experts explain the speed with which bacteria perish on copper surfaces by the multi-targeted nature of copper's effects. After membrane perforation, copper can inhibit any given enzyme that "stands in its way," and stop the cell from transporting or digesting nutrients, from repairing its damaged membrane, and from breathing or multiplying. It is, thus, not surprising that copper and copper compounds have been used by many different civilizations to treat skin diseases, as well as other maladies. The safety of using the copper oxide containing products has been examined in several non-clinical studies and in more than 10 clinical trials. In all the studies, not even one adverse reaction was recorded. The products were found to be non-irritating, nonsensitizing, and safe to use, both when in contact with intact and broken skin (Varkey, 2010).

\section{CONCLuSION}

Freedom from foot odor and foot infection will improve a people's health, specifically among sports and army people, both physically and mentally. Furthermore, it will be benefited by reducing the costs of medical treatment and productive days lost for that treatment. For these reasons configures a homemade topical powder mix of chalcanthite, alum, and clove in treating foot odor. Moreover, it's free of any harmful chemical constituents. The chemical compositions of components of the topical powder mix of chalcanthite, alum, and clove have detected by the XRF, the most important elements in the topical powder mix are Sulfur (S), copper $(\mathrm{Cu})$, aluminum $(\mathrm{Al})$, potassium $(\mathrm{K})$, iron $(\mathrm{Fe})$, and zinc $(\mathrm{Zn})$. The antimicrobial activity of the topical powder mix was found to be effective against Epidermophyton sp., Trichophyton sp., Brevibacterium sp., and Staphylococcus. The growth inhibition zone was found to be high $(28 \mathrm{~mm})$ when mixing chalcanthite, alum, and clove at the same ratio 1:1:1, respectively, and the growth inhibition zone was found to be low $(14 \mathrm{~mm})$ when mixing chalcanthite, alum, and clove at the mixing ratio $0.5: 0.5: 1$, respectively.

I have used the homemade topical powder mix of chalcanthite, alum, and clove for many people, and it's showing a successful positive product in the treatment of foot odor. Complete healing within 3 days only without any side effects.

To the best of our knowledge, this is the first study carried out. There is no previous results were published in this regard.

\section{ACKNOWLEDGMENT}

The author is grateful to the Department of Biology at Baghdad University for antimicrobial activity test and Department of Physics at Koya University for using their facility of XRF technique.

\section{REFERENCES}

Ara, K., Hama, M., Akiba, S., Koike, K., Okisaka, K., Hagura, T., Kamiya, T. and Tomita, F., 2006. Foot odor due to microbial metabolism and its control. Canadian Journal of Microbiology, 52(4), pp.357-364.

Barbaro, S.E. and Symonds, J.A., 2006. The efficacy of a novel Quartenary ammonium foot spray (NQAFS) against foot odor causing microorganisms. Rivier College Online Academic Journal, 2, pp.1.

Bauer, A.W., Kirby, W.M., Sherris, J.C. and Turck, M., 1966. Antibiotic susceptibility testing by a standardized single disk method. American Journal of Clinical Pathology, 45(4), pp.493-496. 
Borkow, G., 2014. Using copper to improve the well-being of the skin. Current Chemical Biology, 8(2), pp.89-102.

CLSI. Clinical and Laboratory Standards Institute., 2012. Performance Standards for Antimicrobial Susceptibility Testing; Twenty-Second Informational Supplement. CLSI Document M 100-S22.

Dawson, K.A. and Boling, J.A., 1987. Effects of potassium ion concentrations on the antimicrobial activities of ionophores against ruminal anaerobes. Applied and Environmental Microbiology, 53(10), pp.2363-2367.

Essa, A.M. and Khallaf, M.K., 2016. Antimicrobial potential of consolidation polymers loaded with biological copper nanoparticles. BMC Microbiology, 16(1), pp.144.

Hobman, J.L. and Crossman, L.C., 2015. Bacterial antimicrobial metal ion resistance. Journal of Medical Microbiology, 64(5), pp.471-497.

Jang, M., 2010. Application of portable X-ray fluorescence (PXRF) for heavy metal analysis of soils in crop fields near abandoned mine sites. Environmental Geochemistry and Health, 32(3), pp.207-216.

Kanda, F., Yagi, E., Fukuda, M., Nakajima, K., Ohta, T. and Nakata, O., 1990. Elucidation of chemical compounds responsible for foot malodour. British Journal of Dermatology, 122(6), pp.771-776.

Kim, S., Kubec, R. and Musah, R.A., 2006. Antibacterial and antifungal activity of sulfur-containing compounds from Petiveria alliacea L. Journal of Ethnopharmacology, 104(1-2), pp.188-192.

Marshall, J., Holland, K.T. and Gribbon, E.M., 1988. A comparative study of the cutaneous microflora of normal feet with low and high levels of odour. Journal of Applied Microbiology, 65(1), pp.61-68.

McWilliams, S.A., Montgomery, I., Jenkinson, D.M., Elder, H.Y., Wilson, S.M. and Sutton, A.M., 1987. Effects of topically-applied antiperspirant on sweat gland function. British Journal of Dermatology, 117(5), pp.617-626.

Oro, D., Heissler, A., Rossi, E.M., Scapin, D., da Silva Malheiros, P. and Boff, E.,
2015. Antifungal activity of natural compounds against Candida species isolated from HIV-positive patients. Asian Pacific Journal of Tropical Biomedicine, 5(9), pp.781-784

Peciulyte, D. and Dirginciute-Volodkiene, V., 2012. Effect of zinc and copper on cultivable populations of soil fungi with special reference to entomopathogenic fungi. Ekologija, 58(2), pp.65-85.

Peng, S., Liu, Z., Sun, T., Ma, Y., and Ding, X., 2013. Spatially resolved in situ measurements of the ion distribution near the surface of an electrode in steadystate diffusion in an electrolytic tank with confocal micro X-ray fluorescence. Analytical Chemistry, 86(1), pp.362-366.

Percival, S.L., Bowler, P.G. and Russell, D., 2005. Bacterial resistance to silver in wound care. Journal of Hospital Infection, 60(1), pp.1-7.

Sharquie, K.E., 1996. Intralesional therapy of cutaneous leishmaniasis with $2 \%$ zinc sulfate solution. Journal Pan Arab League of Dermatologist, 7, pp.41-46.

Sharquie, K.E., Noaimi, A.A. and Hameed, S.D., 2013. Topical 15\% zinc sulfate solution is an effective therapy for feet odor. Journal of Cosmetics, Dermatological Sciences and Applications, 3(03), pp.203-208.

Smaldone, G.T. and Helmann, J.D., 2007. CsoR regulates the copper efflux operon copZA in Bacillus subtilis. Microbiology, 153(12), pp.4123-4128.

Suleiman, M., Al-Masri, M., Al Ali, A., Aref, D., Hussein, A., Saadeddin, I. and Warad, I., 2015. Synthesis of nano-sized sulfur nanoparticles and their antibacterial activities. Journal of Materials and Environmental Science, 6(2), pp.513-518.

Varkey, A.J., 2010. Antibacterial properties of some metals and alloys in combating coliforms in contaminated water. Scientific Research and Essays, 5(24), pp.3834-3839.

Wayne, P.A., 2007. Clinical and laboratory standards institute. Performance Standards for Antimicrobial Susceptibility Testing, 2007, 17.

Yamamoto, K. and Ishihama, A., 2005. Transcriptional response of Escherichia coli to external copper. Molecular Microbiology, 56(1), pp.215-227. 